\title{
Germination test and ornamental potential of different basil cultivars (Ocimum spp. $)^{(1)}$
}

\author{
MATHEUS FILIPE DE MORAES SOUSA FRANÇA ${ }^{(2)}$, MICHELLE SOUZA VILELA ${ }^{(2)}$, ANNE PINHEIRO COSTA ${ }^{(2)}$, \\ ISADORA NOGUEIRA(2), MÁRCIO DE CARVALHO PIRES ${ }^{(2)}$, NARA OLIVEIRA SILVA SOUZA ${ }^{(2)}$
}

\begin{abstract}
Basil (Ocimum spp.) is an essential oil producing plant and it is used as a condiment for diferent foods, besides serving as raw material for medicinal purposes. This crop has also been showing great importance as an ornamental plant in recent years. However, basil lacks studies concerning its different usages with special regards to its ornamental potential. Therefore, this study aimed at evaluating the vegetative development and the ornamental potential of the basil cultivars 'Grecco a Palla' $(O$. minimum), 'Alfavaca Basilicão Vermelho' (O. basilicum), and 'Thai Basil' (O. basilicum), under protected cultivation. The following characteristics were evaluated: germination percentage, germination speed index, plant canopy diameter $(\mathrm{cm})$, leaf and inflorescence length $(\mathrm{cm})$, plant height $(\mathrm{cm})$, and fresh and dry leaf mass $(\mathrm{g})$. The ornamental potential was estimated based on visual evaluations of plant canopy volume; leaf shape, texture, size, and color; stem and flower color; and number of days to flowering. Cultivar 'Thai Basil' presented the highest leaf dry mass and 'Grecco a Palla' showed the highest germination speed index and seed germination percentage. All cultivars bloomed within 60 days after planting and exhibited color and brightness variability, which are desirable traits for a landscape composition. 'Grecco a Palla' stood out for its short and compact inflorescences, dwarf size and globular shape when grown as a potted plant. The studied cultivars demonstrated favorable characteristics for ornamental usage based on visual assessments.
\end{abstract}

Keywords: Ocimum basilicum, Ocimum minimum, ornamental gardening, landscaping, ornamental edible plants.

\section{RESUMO}

Teste de germinação e potencial ornamental de diferentes cultivares de manjericão (Ocimum spp.)

O manjericão (Ociumum spp.) é uma planta produtora de óleos essenciais e é utilizada como condimento para diversos alimentos, além de ser matéria prima para fins medicinais. Essa cultura também tem demosntrado grande importância como planta ornamental nos últimos anos. No entanto, há uma carência de estudos relacionados aos diferentes usos do manjericão, especialmente ao seu potencial ornamental. Portanto, este estudo teve como objetivo avaliar o desenvolvimento vegetativo e o potencial ornamental das cultivares de manjericão 'Grecco a Palla' (O. minimum), 'Alfavaca Basilicão Vermelho' (O. basilicum), and 'Thai Basil' (O. basilicum), em cultivo protegido. Foram avaliadas as seguintes características: porcentagem de germinação, índice de velocidade de germinação, diâmetro do dossel da planta $(\mathrm{cm})$, comprimento da folha e da inflorescência (cm), altura da planta $(\mathrm{cm})$ e massa foliar fresca e seca $(\mathrm{g})$. O potencial ornamental foi estimado por meio de avaliações visuais do volume de dossel da planta; formato, textura, tamanho e cor da folha; cor do caule e da flor; e número de dias até o florescimento. A cultivar 'Thai Basil' apresentou a maior massa seca de folhas e 'Grecco a Palla' mostrou o maior índice de velocidade de germinação e a maior porcentagem de germinação de sementes. Todas as cultivares floresceram dentro de 60 dias após a semeadura e exibiram variabilidade na coloração e brilho, que são características importantes para a composição da paisagem. 'Grecco a Palla' destacou-se por suas inflorescências curtas e compactas, porte anão e formato globular quando cultivada em vasos. As cultivares estudadas demonstraram características favoráveis ao uso ornamental com base em avaliações visuais.

Palavras-chave: Ocimum basilicum, Ocimum minimum, jardinagem ornamental, paisagismo, plantas ornamentais comestíveis.

\section{INTRODUCTION}

The Brazilian flower and ornamental plant section has noticeably advanced in the last years and is now considered as a promising segment in the national agribusiness field (JUNQUEIRA and PEETZ, 2017). However, innovation, diversification, and constant incorporation of news items into the product supply chain are essential to meet the expectations of the increasingly demanding custormers (JUNQUEIRA and PEETZ, 2008; SEBRAE, 2015). Therefore, it is crucial the continuous release of new products or names and concepts for old products which present variability and permanent innovation in the shape, color, presentation, size, odor, and other characteristics that might interest and attract consumers (JUNQUEIRA and PEETZ, 2005; SEBRAE, 2015). 
According to SEBRAE (2015), consumption diversification has been indicated as one of the most markable trends for the development and growth of the flower and ornamental plant segment. Such consumption could be stimulated through the introduction of new species and cultivars adapted to the local cultures, consistent with the new cultural demands for environmental, biodiversity, and sustainability protection. In this context, the ornamental utilization of species commonly used for food, spice, and aromatic purposes becomes very appealing due to the great importance of combining flavors, textures, leaves, and flowers in current landcaping projects.

The Ocimum genus (Family Lamiaceae) includes over 150 different species, 30 of which are native to the tropics and subtropics, with some species naturalized and/or cultivated in temperate areas (LABRA et al., 2004; VIEIRA and SIMON, 2006). These species are coletively named basil, such as $O$. basilicum L., $O$. sanctum, $O$. americanum L., $O$. gratissimum L., O. minimum L., and $O$. tenuiflorum L., and they are considered important herbs and spices worldwide (PANDEY et al., 2014). Basil is part of a multipurpose group of plants widely used for its medicinal properties, in the farmaceutic and cosmetic industries, as well as for its aromatic, culinary, and ornamental characteristics (BLANK et al., 2010). It is a highly aromatic plant, which can be annual or perennial, depending on the region where it is cultivated (CARVALHO FILHO et al., 2006).

In Brazil, basil is cultivated mainly by small farmers in order to commercialize the plant as a condiment (TEIXEIRA et al., 2002). Besides its in natura consumption, basil can also be cultivated to serve as a substrate for the perfumery industries and for beverage and food flavoring, through the extraction of its essential oil (MAROTTI et al., 1996). As stated by Soares et al. (2007), its economic value lies in the exportation of the essential oil reaching significant levels of commercialization in the domestic and international markets. The crop also presents insecticidal and repellent properties (UMERIE et al., 1998), in addition to antimicrobial activities and a good use for grain conservation (MONTESBELMONT and CARVAJAL, 1998).

Ornamental plants can produce visual effects which are associated with the groups or types they belong to (trees, shrubs, vines, herbaceous plants) and to the particular attributes of each plant, such as: the effect of flowers or showy foliage (LORENZI and SOUZA, 2001). Leaf quantity and canopy volume are important characteristics to plants intended for ornamentation since plant canopy may vary depending on the interest and the landscape design (CHAMAS and MATTHES, 2000). In this context, basil stands out for its shrub characteristics and it can be used to compose gardens mainly due to the colors and shapes of its leaves and flowers. Therefore, besides being an edible plant, basil can also be grown for landscaping purposes, in which flowers, leaves and aromatic characteristics present great importance (BARASH, 1998). Its suitability to ornamental use has already been confirmed for some cultivars through the evaluation of plant compactness, color, size and shape of leaves, flowering showiness, and flower color (TOSCANO et al., 2010).
Basil species also present a remarkable color variation, ranging from green to purple, and this is an important trait for classifying leaves, stem, inflorescences, and flowers of plants with ornamental potential (LIRA FILHO, 2002). Color variation is of great importance for ornamental plants trading along with dye production due to the presence of anthocyanin, especially in purple-colored leaf species (PHIPPEN and SIMON, 2000). Flowers and inflorescences are also essential for landscape composition. It has been observed that basil plants with smaller and more compact inflorescences tend to be better utilized for ornamental purposes. Hence, this is an important characteristic to be observed during cultivar selection in breeding programs (MORALES and SIMON, 1996).

The development of agronomic techniques aiming at maximizing medicinal, aromatic, flavouring, and ornamental species cultivation is a way of assuring raw material regular supply, controlling factors that could influence its phytochemical and pharmacological quality (LOURENZANI et al., 2004; PINTO et al., 2008; CHAGAS et al., 2011). However, studies aiming at maximizing the production of basil and other herbs are scarce. Despite its use as an ornamental plant in different parts of the world, reports on the ornamental potential of the different basil species are equally limited. Therefore, the objective of this study was to evaluate the vegetative development and the ornamental potential of the basil cultivars 'Grecco a Palla' (O. minimum), 'Alfavaca Basilicão Vermelho’ ( $O$. basilicum), and 'Thai Basil' (O. basilicum), under protected cultivation.

\section{MATERIAL AND METHODS}

The experiment was conducted in a greenhouse complex $\left(14-30^{\circ} \mathrm{C} ; 61-82 \% \mathrm{ARH}\right)$ and three cultivars of basil were evaluated: 'Grecco a Palla' (O. minimum), 'Alfavaca Basilicão Vermelho' ( $O$. basilicum), and 'Thai Basil' (O. basilicum). According to the seed-producing companies, seeds of 'Alfavaca Basilicão Vermelho' presented $96 \%$ germination rate and $100 \%$ purity; 'Grecco a Palla' presented $85 \%$ germination rate and $99.8 \%$ purity; and 'Thai Basil' seeds, which were directly acquired from an European producer, presented $70 \%$ germination rate and $98 \%$ purity guaranteed by the seed producer.

Seeds were sown on March 23, 2016 in pots containing 4L of autoclaved Red Latosol, $20 \mathrm{~g}$ of sterile chicken manure, and 1L of Bioplant ${ }^{\circledR}$ substrate (Bioplant Agrícola Ltda) containing Pinnus bark, coconut fiber, rice husk, and nutrients. A total of three seeds were sown per pot and plants were thinned to one per pot 30 days after planting. Plants were daily watered during the first 15 days after sowing. After the first 15 days, plants were irrigated from Monday to Saturday up to soil field capacity. Weeds were controlled by hand hoeing.

Seed germination percentage $(\% \mathrm{G})$ was determined as the mean of germinated plants observed in 15 counts. First count was performed on the first day after planting. Seeds were considered germinated when cotyledonary leaves were displayed above soil surface. 
Germination speed index (GSI) was determined dividing the number of normal seedlings germinating on each day by the number of days elapsed since germination test began, and then summing the quotients, in accordance with the Maguire's formula (1962):

$\mathrm{GSI}=\left(\mathrm{G}_{1} / \mathrm{N}_{1}\right)+\left(\mathrm{G}_{2} / \mathrm{N}_{2}\right)+\left(\mathrm{G}_{3} / \mathrm{N}_{3}\right)+\ldots+\left(\mathrm{G}_{\mathrm{n}} / \mathrm{N}_{\mathrm{n}}\right)$,

where:

GSI = Germination Speed Index;

$\mathrm{G}_{1}, \mathrm{G}_{2}, \mathrm{G}_{3}, \ldots, \mathrm{Gn}=$ Number of normal seedlings computed in the first, second, third, and final count;

$\mathrm{N}_{1}, \mathrm{~N}_{2}, \mathrm{~N}_{3}, \ldots, \mathrm{Nn}=$ Number of days to first, second, third, and final count.

Plant canopy diameter $(\mathrm{cm})$, leaf and inflorescence lengths $(\mathrm{cm})$, plant height $(\mathrm{cm})$, and leaf fresh and dry masses (g) were taken from 60-day-old plants. Inflorescence length was measured from the rachis to the top of inflorescence and plant height was measured as the distance between soil surface and the tip of the highest part of the plant. Leaf fresh mass was determined after manually harvesting and weighting all leaves from each plant. Leaves were then oven-dried at $70 \pm 2{ }^{\circ} \mathrm{C}$ to constant weight, in order to obtain leaf dry mass.

The experiment consisted of a randomized block design (RDB) with three treatments (cultivars), three replications per cultivar, and three repetitions. Data were submitted to analysis of variance (ANOVA) and Tukey's test ( $p<$ 0.05) using Genes software (CRUZ, 2007). Square-root transformation was applied to ensure normal distribution of the variables.

Additionally, given the scarcity of studies on the use of basil for landscaping purposes, a descriptive study was carried out in order to evaluate characteristics of these cultivars considering their possible use as ornamental plants. Hence, assessments of the visual effects of these cultivars were performed 60 days after sowing. Canopy volume; leaf shape, texture, size, and color; stem and flower color; and number of days to flowering were estimated according to studies containing basil characteristics which were developed by Phippen and Simon (2000) and Lorenzi and Souza (2001).

\section{RESULTS AND DISCUSSION}

Differences between genotypes were observed for leaf dry mass (Table 1). This trait may affect essential oil yields on basil plants (SIMON et al., 1999) and it is closely related to leaf fresh mass, which is generally related to leaf length. Among the cultivars studied, 'Thai Basil' presented the highest leaf dry mass $(0.08 \mathrm{~g})$ whereas 'Grecco a Palla' showed leaf dry mass close to zero (Table 1).

Table 1. Seed germination percentage $(\% \mathrm{G})$, germination speed index (GSI), canopy diameter (CD; cm), leaf length (LL; cm), inflorescence length (IL; cm), plant height (PH; cm), leaf fresh mass (LFM; g), and leaf dry mass (LDM; g) in basil cultivars 'Grecco a Palla' (Ocimum minimum), 'Alfavaca Basilicão Vermelho' (O. basilicum), and 'Thai Basil' (O. basilicum), Brasilia, DF, 2016.

$\begin{array}{cccccccccc}\text { CULTIVAR } & \text { \%G } & \text { GSI } & \text { CD } & \text { LL } & \text { IL } & \text { PH } & \text { LFM } & \text { LDM } \\ \text { 'Grecco a Palla' } & 88.87 \mathrm{a} & 2.02 \mathrm{a} & 42.42 \mathrm{a} & 2.68 \mathrm{a} & 1.49 \mathrm{a} & 29.58 \mathrm{a} & 0.06 \mathrm{a} & 0.00 \mathrm{~b} \\ \text { 'Alfavaca Basilicão Vermelho' } & 22.23 \mathrm{a} & 1.04 \mathrm{a} & 22.13 \mathrm{a} & 4.85 \mathrm{a} & 6.50 \mathrm{a} & 22.81 \mathrm{a} & 0.44 \mathrm{a} & 0.04 \mathrm{ab} \\ \text { 'Thai Basil' } & 54.95 \mathrm{a} & 0.96 \mathrm{a} & 37.31 \mathrm{a} & 6.34 \mathrm{a} & 12.39 \mathrm{a} & 35.00 \mathrm{a} & 0.46 \mathrm{a} & 0.08 \mathrm{a}\end{array}$

Mean separation in columns by Tukey's test. Different lowercase letters within columns indicate significant differences $(\mathrm{P} \leq 0.05)$.

This result could possibly be explained by the fact that 'Thai Basil' (O. tenuiflorum, O. basilicum var. thyrsiflora, and $O$. sanctum) usually presents bigger size than the other cultivars studied, as 'Grecco a Palla', that is known by its small leaves and size (SIMON et al., 1999). Nevertheless, cultivars may present developmental differences according to the cultivation region, different latitude and altitude conditions, and soil and climatic conditions (SIMON et al., 1999; MEYERS, 2003). Further associations are difficult to be performed, as there is a lack of studies about this cultivar in Brazil and in the world.

'Grecco a Palla' presented a better performance concerning \%G (88.87\%) and GSI (2.02) as compared to the other cultivars (Table 1). Seed vigor, the most important seed quality attribute, represents a set of factors that results in the seed potential to germinate, emerge, and rapidly produce normal seedlings under climatic diversity. The lower the degree of seed decay, the greater its vigor, and this is directly related to GSI and to $\% \mathrm{G}$. GSI is an index calculated from the germinated plant count data, which aims to establish the germination speed of a seed lot when compared to others. In the case of high $\% \mathrm{G}$, it is possible to affirm that the seed is in good physical and chemical conditions, increasing the precision of competition tests (KRZYZANOWSKI and NETO, 2001).

Moreover, 'Grecco a Palla' was the only cultivar presenting similar $\% \mathrm{G}$ to the one provided by the seed producer in its original packaging. The remaining cultivars exhibited $\% \mathrm{G}$ 
well below the suppliers' information. These results could be due to differences in the cultivation sites, cultivation techniques, and edaphoclimatic and storage conditions.

When considering characteristics with ornamental potential, such as canopy diameter, it was verified that cultivars 'Grecco a Palla' (42.42 cm) and 'Thai Basil' (37.31 $\mathrm{cm})$ presented greater values than 'Alfavaca Basilicão Vermelho’ (22.23 cm) (Table 1), although no significant differences were detected among cultivars. This feature is important in terms of the number of leaves and the volume these leaves can occupy, both presenting great relevance when chosing a cultivar to be used for ornamental purposes (CHAMAS and MATTHES, 2000). 'Grecco a Palla' also stood out for its dwarf size when grown as a potted plant (Figure 1), exhibiting a globular shape, almost perfectly spherical, not requiring topiary pruning.

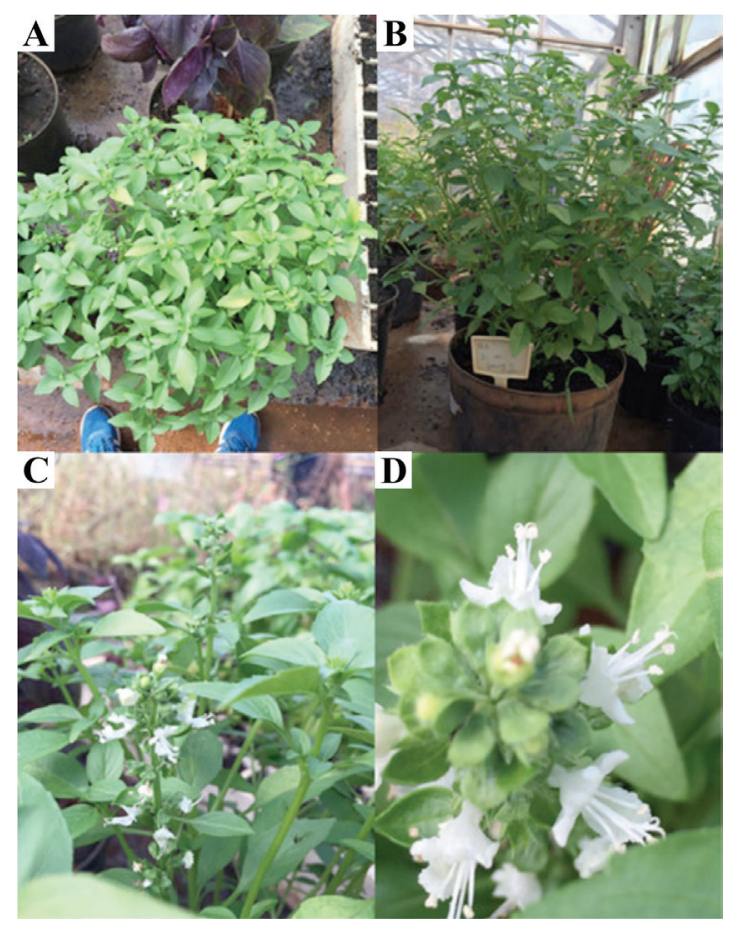

Figure 1. Basil cultivar 'Grecco a Palla' (Ocimum minimum). A-B) Plant architecture. C-D) Inflorescence.

Inflorescence length presents commercial interest for both seed production and ornamental purposes. Size, color, and flower durability are characteristics of great importance. 'Grecco a Palla' and 'Alfavaca Basilicão Vermelho' showed the shortest inflorescence lengths in contrast to 'Thai Basil' (Table 1; Figures 1, 2 and 3). Therefore, 'Grecco a Palla' and 'Alfavaca Basilicão Vermelho' tend to exhibit smaller and more compact inflorescences, which are preferred for landscaping purposes (MORALES and SIMON, 1996). 


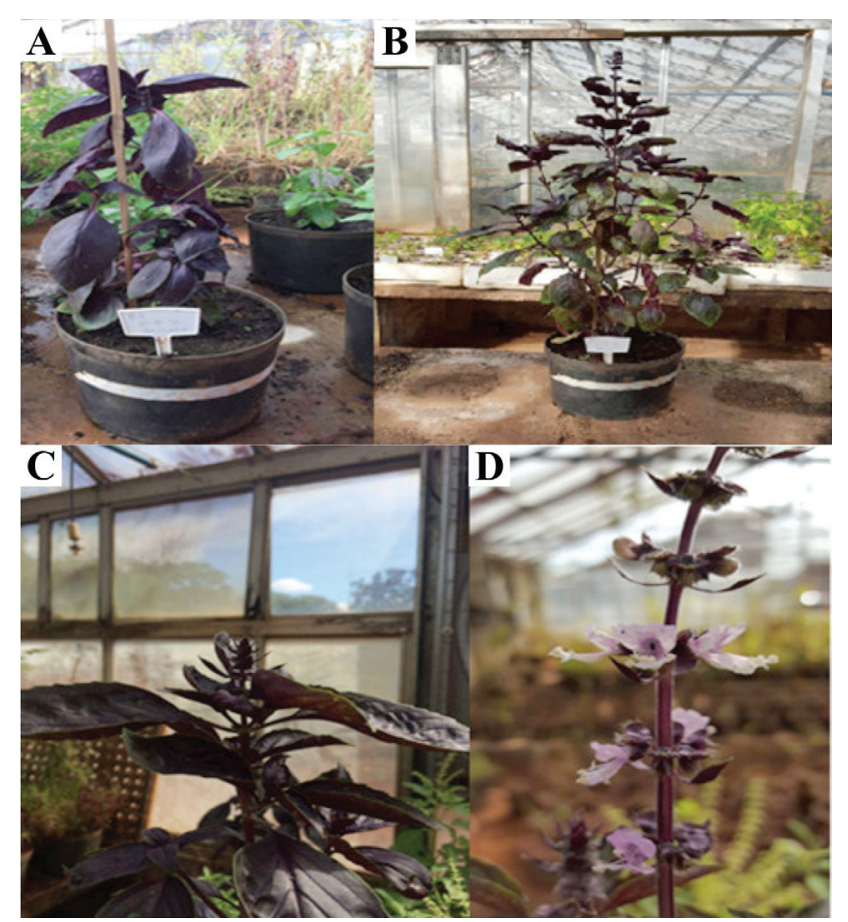

Figure 2. Basil cultivar 'Alfavaca Basilicão Vermelho’ (Ocimum basilicum). A-B) Plant architecture. C-D) Inflorescence.

Cultivar 'Grecco a Palla' bloomed 40 days after sowing, Basil' developed inflorescences 48 days after sowing and showing white-colored flowers (Figure 1), whereas 'Thai light lilac flowers were visualized 7 days ahead (Figure 3 ).

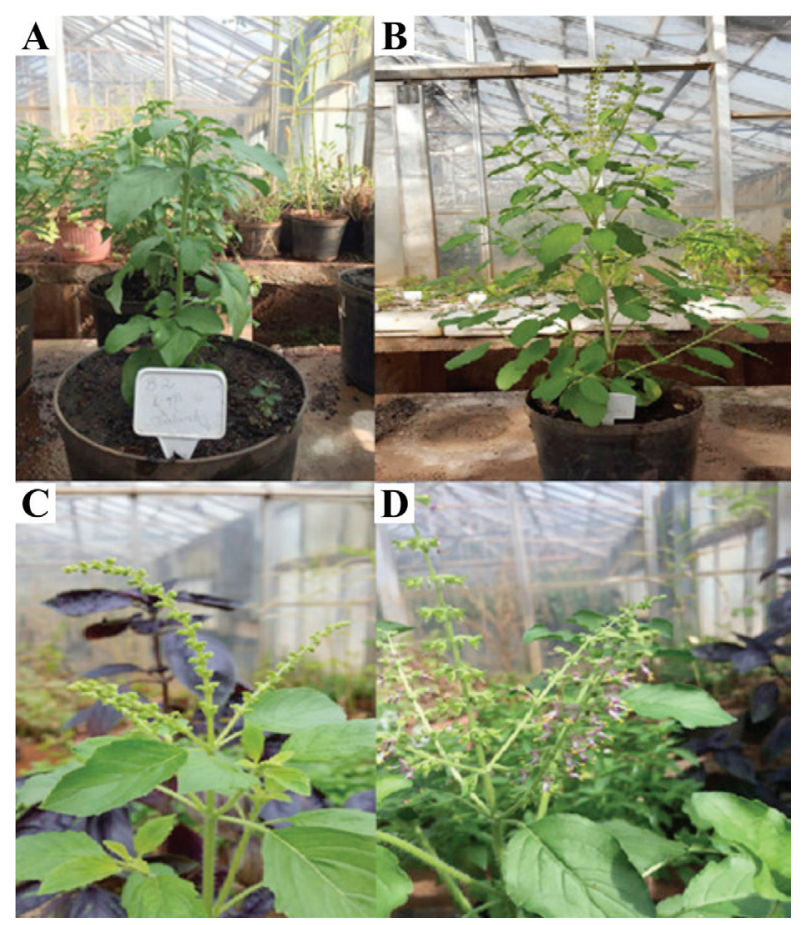

Figure 3. Basil cultivar 'Thail basil’ (Ocimum basilicum). A-B) Plant architecture. C-D) Inflorescence.

'Alfavaca Basilicão Vermelho' displayed inflorescences 55 days after sowing and dark lilac flowers were visualized 5 days ahead (Figure 2). It is noteworthy that culitvar 'Grecco a Palla' remained flowering until the last evaluation.
Consistent with Biondi (1990), it is possible to evaluate plant texture merely by referring to leaf size. Plants with small and delicate leaves are classified as fine texture plants and those with large leaves are classified as thick 
texture plants. Based on this description, 'Thai basil' and 'Alfavaca Basilicão Vermelho' were classified as thick texture plants for presenting large and resistant leaves, with rigid petioles. Cultivar 'Grecco a Palla' could not fit into one classification as it showed small but resistant leaves.

Regarding plant colors and brightness, 'Grecco a Palla' and 'Thai basil' exhibited green stems and lemonish-green and opaque green leaves, respectively (Figures 1 and 3). In contrast, 'Alfavaca Basilicão Vermelho' showed purple stem and purple/green leaves (Figure 3). Green spots were visualized in the purple leaves and could possibly be explained by anthocyanin conversion due to the lack of sun incidence (PHIPPEN and SIMON, 2000). Differently from the other cultivars studied, 'Alfavaca Basilicão Vermelho' presented a waxy brightness instead of an opaque one. The color variability identified in this study represents an interesting feature when choosing foliage plants for a landscape composition and it is of great importance for the ornamental plants trading (PHIPPEN and SIMON, 2000).

The need for diversification in the ornamental plant trading increases mainly due to the greater demand from the modern consumers as well as to the new landscaping concepts committed to human welfare. Consequently, it has been observed that plants previously used solely for food and medicinal purposes are now being cultivated as ornamentals. In this context, basil is noteworthy for its ornamental characteristics, including plant shape, leaves, flowers, and inflorescences, in addition to the value aggregated by its odor and suitability to compose an edible garden.

\section{CONCLUSIONS}

Cultivar 'Grecco a Palla' presented superior seed germination percentage and seedling development when compared to 'Thai Basil' and 'Alfavaca Basilicão Vermelho'. 'Thai Basil' exhibited the highest leaf dry mass. All three cultivars showed favorable characteristics for ornamental usage based on visual evaluations.

\section{AUTHORS CONTRIBUTIONS}

M.F.M.S.F.: field analysis, data collection and analysis, manuscript preparation and review. M.S.V.: data analysis and interpretation, manuscript critical review, approval of the final version of the manuscript. A.P.C.: manuscript preparation, critical review and translation, approval of the final version of the manuscript. I.N.: manuscript preparation and review. M.C.P.: manuscript review. N.O.S.S.: manuscript review.

\section{REFERENCES}

BARASH, C.W. The flavors of flowers. Herb Companion, v.10, n.4, p.32-37, 1998.

BIONDI, D. Paisagismo. Recife: Imprensa Universitária da UFRPE, 1990. 184p.
BLANK, A.F; SOUZA, E.M.; PAULA, J.W.A.; ALVES, P.B. Comportamento fenotípico e genotípico de populações de manjericão. Horticultura Brasileira, v.28, n.3, p.305-310, 2010. DOI: <https://doi.org/10.1590/S010205362010000300011>

CARVALHO FILHO, J.L.S.; ALVES, P.B.; EHLERT, P.A.D.; MELO, A.S.; CAVALCANTI, S.C.H.; ARRIGONIBLANK, M.F.; SILVA-MANN, R.; BLANK, A.F. Influence of the harvesting time, temperature and drying period on basil (Ocimum basilicum L.) essential oil. Revista Brasileira de Farmacognosia, v.16, p.24-30, 2006. DOI: $<$ https://doi.org/10.1590/S0102-695X2006000100007>

CHAGAS, J.H.; PINTO, J.E.B.P.; BERTOLUCCI, S.K.V.; SANTOS, F.M. Produção de biomassa e teor de óleo essencial em função da idade e época de colheita em plantas de hortelã-japonesa. Acta Scientiarum. Agronomy, v.33, n.2, p.327-334, 2011. DOI: <https://doi.org/10.4025/ actasciagron.v33i2.5698>

CHAMAS, C.C.; MATTHES, L.A.F. Método para levantamento de espécies nativas com potencial ornamental. Revista Brasileira de Horticultura Ornamental, v.6, n.1/2, p.53-63, 2000. DOI: <https://doi.org/10.14295/rbho. v6i1.63>

CRUZ, C.D. Programa Genes: Versão Windows; aplicativo computacional em genética e estatística. Viçosa: Universidade Federal de Viçosa, 2007. (CD-ROM).

JUNQUEIRA, A.H.; PEETZ, M.S. Brazilian consumption of flowers and ornamental plants: habits, practices and trends Ornamental Horticulture, v.23, n.2, p.178-184, 2017 DOI: <http://dx.doi.org/10.14295/oh.v23i2.1070>

JUNQUEIRA, A.H.; PEETZ, M.S. Mercado interno para os produtos da floricultura brasileira: características, tendências e importância socioeconômica recente. Revista Brasileira de Horticultura Ornamental, v.14, n.1, p.3752, 2008.

JUNQUEIRA, A.H.; PEETZ, M.S. Perfil da Cadeia Produtiva de Flores e Plantas Ornamentais do Distrito Federal. Brasília: SEBRAE/DF, 2005. 121p.

KRZYZANOWSKI, F.C.; NETO, J.B.F. Vigor de sementes. Informativo Abrates, v.11, n.3, p.81-84, 2001.

LABRA, M.; MIELE, M.; LEDDA, B.,; GRASSI, F.; MAZZEI, M.; SALA, F. A Morphological characterization: the essential oil composition and DNA genotyping of Ocimum basilicum L. cultivars. Plant Science, v.167, p.725-773, 2004. DOI: <https://doi.org/10.1016/j. plantsci.2004.04.026>

LIRA FILHO, J.A. Paisagismo: elementos de composição e estética. Coleção Jardinagem e paisagismo, v. 2. Viçosa: Editora Aprenda Fácil, 2002. 194p. 
LORENZI, H.; SOUZA, H. M. Plantas Ornamentais no Brasil - arbustivas, herbáceas e trepadeiras. 3 rd ed. Nova Odessa: Instituto Plantarum, 2001. 1088p.

LOURENZANI, A.E.B.S.; LOURENZANI, W.L.; BATALHA, M.O. Barreiras e oportunidades na comercialização de plantas medicinais provenientes da agricultura familiar. Informações Econômicas, v.34, n.3, 2004.

MAGUIRE, J.D. Speed of germination aid in selection and evaluation for seedling emergence and vigor. Crop Science, v.2, n.1, p.176-177, 1962. DOI: <https://doi. org/10.2135/cropsci1962.0011183X000200020033x>

MAROTTI, M.; PICCAGLIA, R.; GIOVANELLI, E. Diferences in essencial oil composition of basil (Ocimum basilicum L.) italian cultivars related to morfological characteristics. Journal of Agricultural and Food Chemistry, v.44, n.12, p. 3926-3929, 1996. DOI: <https:// doi.org/10.1021/jf9601067>

MEYERS, M. Basil: An Herb Society of America Guide. Kirtland: The Herb Society of America, 2003. 45p.

MONTES-BELMONT, R.; CARVAJAL, M. Control of Aspergillus flavus in maize with plant essential oils and their components. Journal of Food Protection, v.61, n.5, p.616-619, 1998. DOI: <https://doi.org/10.4315/0362028X-61.5.616>

MORALES, M.R.; SIMON, J.E. New basil selections with compact inflorescences for the ornamental market. In: JANICK, J. Progress in new crops. Alexandria: ASHS Press, 1996. p.543-546.

PANDEY, A.K.; SINGH, P.; TRIPATHI, N.N. Chemistry and bioactivities of essential oils of some Ocimum species: an overview. Asian Pacific Journal of Tropical Biomedicine, v.4, n.9, p.682-694, 2014. DOI: <https://doi. org/10.12980/APJTB.4.2014C77>

PHIPPEN, W.B.; SIMON, J.E. Anthocianin inheritance and instability in purple basil. The Journal of Heredity, v.91, n.4, p.289-296, 2000. DOI: <https://doi.org/10.1093/ jhered/91.4.289>
PINTO,D.S.; TOMAZ,A.C.A.; TAVARES, J.F.; TENÓRIOSOUZA, F.H.; DIAS, C.S.; BRAZ-FILHO, R.; CUNHA, E.V.L. Secondary metabolites isolated from Richardia brasiliensis Gomes (Rubiaceae). Revista Brasileira de Farmacognosia, v.18, n.3, p.367-372, 2008. DOI: <https:// doi.org/10.1590/S0102-695X2008000300010>

SEBRAE - Serviço Brasileiro de Apoio às Micro e Pequenas Empresas. Flores e plantas ornamentais do Brasil. Série Estudos Mercadológicos, v.3. Brasília: SEBRAE, 2015. $25 \mathrm{p}$.

SIMON, J.E., MORALES, M.R., PHIPPEN, W.B., VIEIRA, R.F., HAO, Z. Basil: a source of aroma compounds and a popular culinary and ornamental herb. In: JANICK, J. New crops and new uses: biodiversity and agricultural sustainability. Alexandria: ASHS Press, 1999. p.12-159.

SOARES, R.D.; CHAVES, M.A.; SILVA, A.A. L.; SILVA, M.V.; SOUZA, B.S. Influência da temperatura e velocidade do ar na secagem de manjericão (Ocimum basilicum L.) com relação aos teores de óleos essenciais e de linalol. Ciência e Agrotecnologia, v.31, n.4, p.1108-1113, 2007. DOI: $<$ https://doi.org/10.1590/S1413-70542007000400025>

TEIXEIRA, J.P.F.; MARQUES, M.O.M.; FURLANI, P.R.; FACANALLI, R. Essential oil contents in two cultivars of basil cultivated on NFT-hydroponics. Acta Horticulturae, v.569, p.203-208, 2002. DOI: <https://doi.org/10.17660/ ActaHortic.2002.569.32>

TOSCANO, S.; SCUDERI, D.; NOTO, G. Ornamental edible plants in urban horticulture. Acta Horticulture, v.881, p.137-140, 2010. DOI: $<$ https://doi.org/10.17660/ActaHortic.2010.881.14> UMERIE, S.C.; ANASO, H.U.; ANYASORO, L.J.C. Inseticidal potentials of Ocimum basilicum leaf extracts. Bioresource Technology, v.64, n.3, p.237-239, 1998. DOI: $<$ https://doi.org/10.1016/S0960-8524(97)00188-0>

VIEIRA, R.F.; SIMON, J.E. Chemical characterization of basil (Ocimum spp.) based on volatile oils. Flavour and Fragance, v.21, p.214-221, 2006. 